\title{
Ultrastructure of the eggs of two species of Anopheles (Anopheles) Meigen (Diptera, Culicidae) ${ }^{1}$
}

\author{
Maria Anice Mureb Sallum² \& Daniel Corugedo Flores
}

\begin{abstract}
${ }^{1}$ This work is supported by Grant no 99/10517-1 from Fundação de Amparo à Pesquisa do Estado de São Paulo (FAPESP), Brazil. ${ }^{2}$ Departamento de Epidemiologia, Faculdade de Saúde Pública, Universidade de São Paulo. Av. Dr. Arnaldo, 715, 01246-904 São Paulo-SP, Brazil.
\end{abstract}

\begin{abstract}
Egg ultrastructure of two morphologicaly similar species of the Arribalzagia Series, Anopheles (A.) costai Fonseca \& Ramos, 1939 and A. (A.) mediopunctatus (Lutz, 1903) are described and illustrated using scanning electron micrographs. Although similar in the adult stage, male genitalia structures and larval and pupal stages, the eggs of these species are distinct. The eggs of $A$. costai and A. mediopunctatus are compared with that of $A$. forattinii Wilkerson \& Sallum, 1999. Incomplete illustration of egg of $A$. forattinii is provided for comparison.
\end{abstract}

Keywords. Anopheles; Arribalzagia; Culicidae; egg; ultrastructure.

Resumo. Ultraestrutura dos ovos de duas espécies de Anopheles (Anopheles) Meigen, 1818 (Diptera, Culicidae). A ultraestrutura dos ovos de duas espécies morfologicamente semelhantes da Série Arribalzagia, Anopheles (A.) costai Fonseca \& Ramos, 1939 and $A$. (A.) mediopunctatus (Lutz, 1903), é descrita e ilustrada usando-se microscopia eletrônica de varredura.. Embora sejam morfologicamente semelhantes nos estádios adulto, estruturas da genitalia masculina, larva de quarto estádio e pupa, os ovos destas duas especies são distintos. Os ovos de A. costai e A. mediopunctatus são comparados com os de $A$. forattinii Wilkerson \& Sallum, 1999. Apresenta-se a ilustração incompleta do ovo de $A$. forattinii para comparação com os ovos das outras duas espécies.

Palavras-Chave. Anopheles; Arribalzagia; Culicidae; ovo; ultraestrutura.

Anopheles (Anopheles) costai Fonseca \& Ramos, 1939 and A. (A.) forattinii Wilkerson \& Sallum, 1999 have been largely misidentified as A. (A.) mediopunctatus (Lutz, 1903). The taxonomic status of these three taxa was clarified by SALLUM et al. (1999) and WilKerson \& SALLum (1999). These authors also defined several morphological characters useful to distinguish the three species, which are members of the Arribalzagia Series as defined by Wilkerson \& PeYton (1990). The Arribalzagia Series was demonstrated to be a monophyletic group within the subgenus Anopheles by Sallum et al. $(2000,2002)$. As far as it is known, $A$. mediopunctatus occurs on the coastal region of Brazil in the states of Rio de Janeiro and São Paulo, whereas $A$. costai is known from Argentina, Bolivia, Brazil, Colombia, Ecuador, the Guianas, Mexico, Panama, Peru, Suriname, Trinidad Tobago and Venezuela (Sallum et al., 1999), and Anopheles forattinii is known from Amazonian Brazil, Peru, Colombia and French Guiana (Wilkerson \& Sallum 1999; Pecor et al. 2000). The only illustrations of eggs of several specimens identified as $A$. mediopunctatus from distinct localities in Brazil are those of CAUSEY et al. (1944). These authors also suggested characters which could be useful to separate several species of the genus Anopheles. However, based on characters given in their identification key, as well as in the small illustrations, it is possible to recognize that eggs identified as being of $A$. mediopunctatus in Plate I and in drawing $\mathrm{h}$ in Plate II may belong to A. costai or A. forattinii, whereas drawing j in Plate
II seems to be the egg of $A$. mediopunctatus. The present study describes the ultrastructure of the egg of two species of the Arribalzagia Series, A. mediopunctatus and A. costai and compare them with egg of $A$. forattinii, and with those of morphologically similar species of this series that were also described using scanning electron microscopic (RoDRIGUEZ et al. 2002; Lounibos et al. 1997; ForATtini et al., 1997).

\section{MATERIAL AND METHODS}

Eggs were obtained from seven females of $A$. costai, three of $A$. mediopunctatus and one of $A$. forattinii. Adults of $A$. costai and $A$. mediopunctatus were collected in a Shannon trap in Icapara, Iguape municipality (240 $\left.42^{\prime} 29^{\prime \prime} \mathrm{S} 47^{0} 33^{\prime} 19^{\prime \prime} \mathrm{W}\right)$, State of São Paulo, Brazil. A female of $A$. forattinii was collected in Iquitos, Peru. Eggs for SEM micrographs were obtained using the same procedure described by ForatTIN et al. (1997). Eggs were allowed 36 hours to embrionate, then 20 eggs from each oviposition were transferred to vials containing Bouin's fixative. The remaning eggs of each species were allowed to hatch and immatures were raised to adults for morphological identification of species using male genitalia structures. Length and width dimension of living eggs were measured with a stereomicroscope and digital length-measuring set. Eggs were examined in JEOL JSM P15 scanning electron microscope (Akishima, Tokyo, Japan). A full description of the egg of the egg of $A$. forattinii was not possible because we were enable 
to obtain a large amount of eggs in adequate condition for the study. For this reason, the egg of $A$. forattinii was only used for comparison, and for the illustration of few characters. Voucher specimens are deposited in the entomological collection of Faculdade de Saúde Pública, Universidade de São Paulo, Brazil (FSP-USP).

\section{RESULTS}

Anopheles (Anopheles) costai Fonseca \& Ramos, 1939 (Figs. 1, 2)

Anopheles (Shannoniella) costai Fonseca \& Ramos 1939: 385.

Size: width $189-222 \mu \mathrm{m}$ (mean $=204 \mu \mathrm{m}+0.01)$, length 485 $-522 \mu \mathrm{m}($ mean $=501 \mu \mathrm{m}+0.01)$, ratio of length to width 2.28 -2.64 (mean $=2.46+0.1)(\mathrm{n}=82$ eggs from 7 females $)$.

Overall appearance. Black, boat-shaped in dorsal and lateral views (Fig. 1A; 2C), in lateral view contour is more or less flat dorsally and curved ventrally (Fig. 2C). Floats wide, lateral in position, long, well developed, extending most of egg length except at anterior and posterior ends (Figs. 1A; $2 \mathrm{C}, \mathrm{D}, \mathrm{E}, \mathrm{F})$; frill not continuous with floats, frill positioned dorsally at anterior and posterior ends, delimiting area in which lobed tubercles are placed (Fig. 1A,B,C).

Dorsal surface. Deck wide, slightly narrow at both anterior and posterior ends. Deck tubercles irregular in shape, forming well defined pattern of hexagonal outer chorionic cells with distinct boundaries, chorionic cells longer than wide, long dimension oriented in long axis of egg (Fig. 2A,B). Interior of each cell formed of round, flat tubercles, connected by narrow bridges, each chorionic cell surrounded by slightly raised outer chorionic reticulum formed of tubercles similar to those placed inside cells (Fig. 2A,C). Tubercles present on both anterior and posterior areas, which are encircled by frills, irregularly shaped with tiny tubercles intermixed with larger irregular in outline, more prominent tubercles, tubercle walls with vertical ridges and clefts (Fig. 1D,E,F).

Anterior and posterior ends. Similar in form, shape and development, however posterior end is slightly narrower than anterior end. Frill forming narrow dorsal ridge, collar-like, placed at both anterior and posterior ends; inner surface of frill irregular with tiny ridges (Fig. 1D,E,F). Area encircled by collar irregular in shape, longer than wide, somewhat oval in outline (Fig. 1D,E). Lobed tubercles well developed, 2,3 in number, somewhat oval or round in shape, tubercle wall covered with tiny ridges. Number of lobes per tubercle variable (Fig. 1D-F). Micropylar collar separated from anterior margin of frill by narrow area (Fig. 2D). Micropylar collar surface smooth, inner edge excavated, peaks between excavations tapering to form radial ridges, dividing micropylar disk into sectors (Fig. 2D).

Ventral and lateral surfaces. Plastron uniformly covered with pentagonal or hexagonal outer chorionic cells, each cell longer than wide, long dimension oriented in long axis of egg except for anterior and posterior ends (Fig. 2F). Interior of each cell formed of small, flat tubercles, irregular in shape and connected by narrow bridges, each chorionic cell surrounded by outer chorionic reticulum formed of slightly raised, irregularly shaped tubercles similar to those inside cells (Fig. $2 \mathrm{~F}$ ). Floats long, well developed, extending from anterior to posterior end of egg (Fig. 2C); ribs about 32-35 in number, slightly divided into irregular lobes (Fig. 2A,C,F).

Anopheles (Anopheles) mediopunctatus (Lutz, 1903) (Fig. 3)

Cycloleppteron mediopunctatus Lutz, 1903 in Theobald, 1903: 60

Size: width $164-209 \mu \mathrm{m}$ (mean $=186 \mu \mathrm{m}+0.01)$, length 534 $-594 \mu \mathrm{m}($ mean $=567 \mu \mathrm{m}+0.01)$, ratio of length to width 2.69 -3.48 (mean $=3.06+0.2)(n=70$ eggs from 3 females).

Overall appearance. Black, boat-shaped in dorsal (Fig. 3A) and lateral views (not shown). Floats long, shallow, displaced far ventrally (Fig. 3A,I). Frill well developed, forming ridges that extend along dorsal surface of egg, encircling deck and both anterior and posterior poles (Fig. 3C,H). Striation of dorsal ridge oblique and coalesced into whorls (Fig. 3A,B,G). Lobed tubercles well developed, present on both anterior and posterior poles, placed inside boundaries of frill (Fig. 3B,C,G,H).

Dorsal surface. Deck narrow, completely enclosed by dorsal ridges. Deck tubercles irregularly shaped, larger tubercles intermixed with tiny tubercles (Fig. 3F); tubercles placed at anterior and posterior ends around lobed tubercles somewhat larger than remaining deck tubercles (Fig. 3C,H). Each deck tubercle irregular in outline (Fig. 3C,F,H), tubercles at anterior and posterior ends with walls with vertical ridges and clefts, irregular at top (Fig. 3C,H). Dorsal area between frill and floats uniformly covered with hexagonal chorionic cells, each cell longer than wide, long dimension oriented in long axis of eggs (Fig. 3A,E). Interior of each chorionic cell formed of small, somewhat flat tubercles connected by narrow bridges. Outer chorionic reticulum of each chorionic cell formed of slightly raised tubercles similar to those inside chorionic cells.

Anterior and posterior ends. Frill well developed, continuous, encircling both anterior and posterior poles of egg (Fig. 3C,H), posterior end (Fig. 3G) slightly narrower than anterior end (Fig. 3B). Lobed tubercles placed dorsally on both anterior and posterior poles of egg, around 5 in number, somewhat oval in outline, walls covered with tiny ridges; number of lobes per lobed tubercle variable (Fig. 3C,H). Micropyle situated at anterior end of egg in center of low mound, micropylar collar smooth, inner boundary nearly straight between sectors and divided into sectors by short rays, which extend from collar to mycrophylar disk (Figs. 3D).

Ventral and lateral surfaces. Ventral and lateral surfaces uniformly covered with well defined, hexagonal outer chorionic cells, most cells longer than wide, long dimension oriented in long axis of egg (Fig. 3D,I). Interior of each cell covered with tubercles nearly round in outline and somewhat flat and 

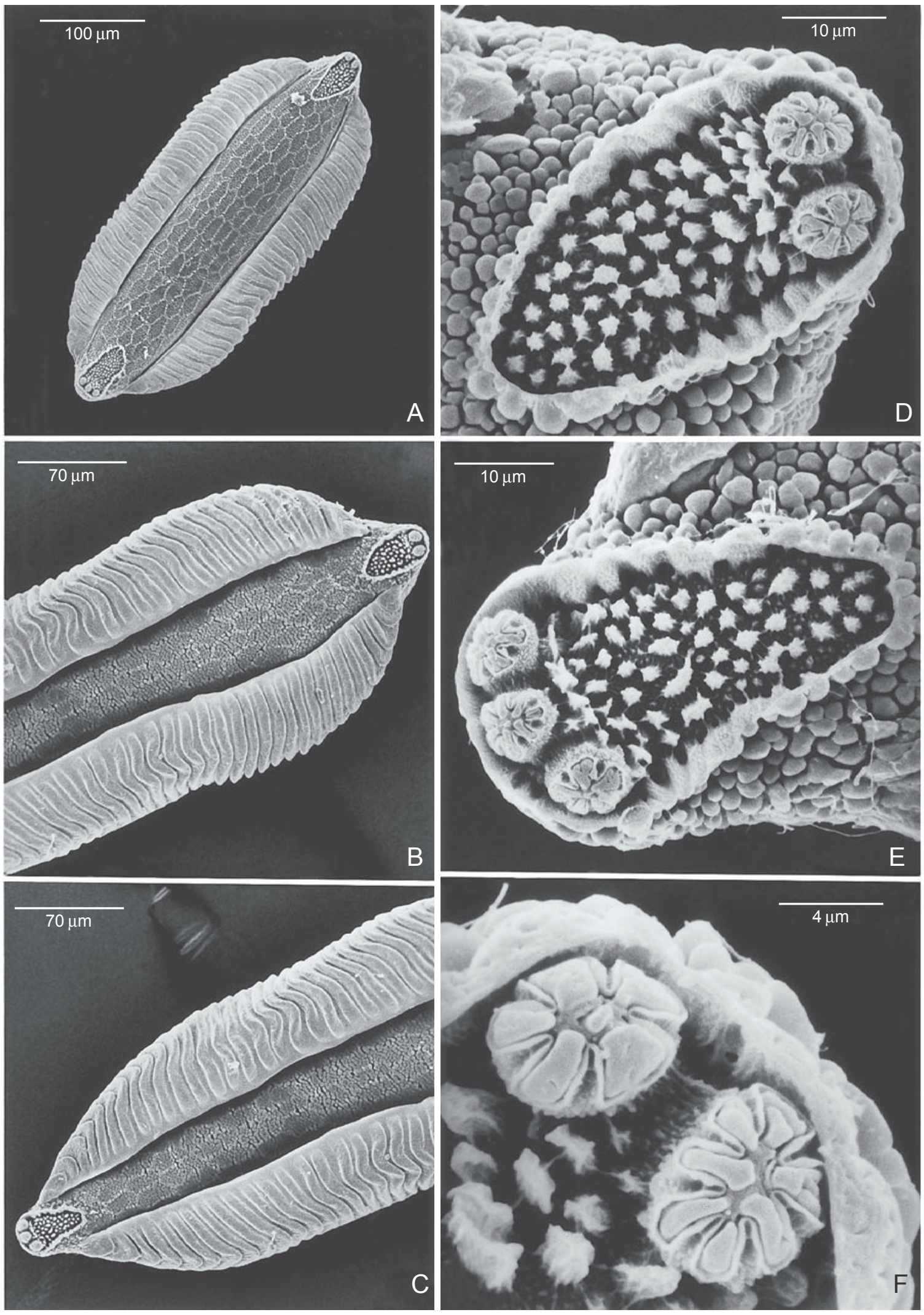

Fig. 1. Egg of Anopheles (Anopheles) costai. A, entire egg, anterior end at top, dorsal view; B, anterior end, dorsal view; C, posterior end, dorsal view; D, detail of anterior end, showing lobed tubercles and frill, dorsal view; E, detail of posterior end, showing lobed tubercles and frill, dorsal view; F, detail of lobed tubercles at anterior end. 

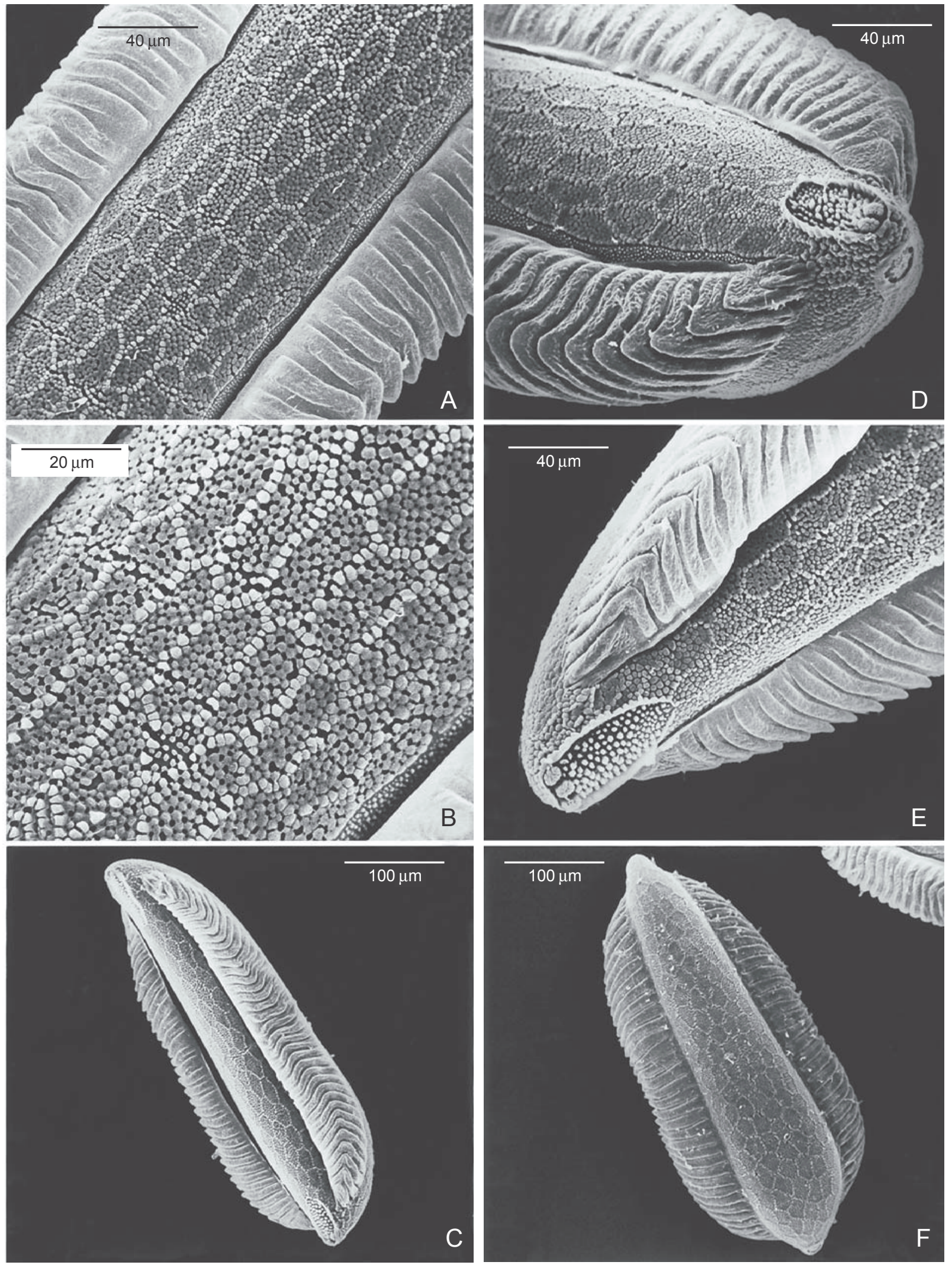

Fig. 2. Egg of Anopheles (Anopheles) costai. A, deck, middle region showing outer chorionic cells and floats; B, detail of deck, middle region; C, entire egg in dorsolateral view, anterior end at right top; D, anterior pole, showing microphyle; E, posterior end, in dorsolateral view; F, entire egg, anterior end at right top, ventral view. 

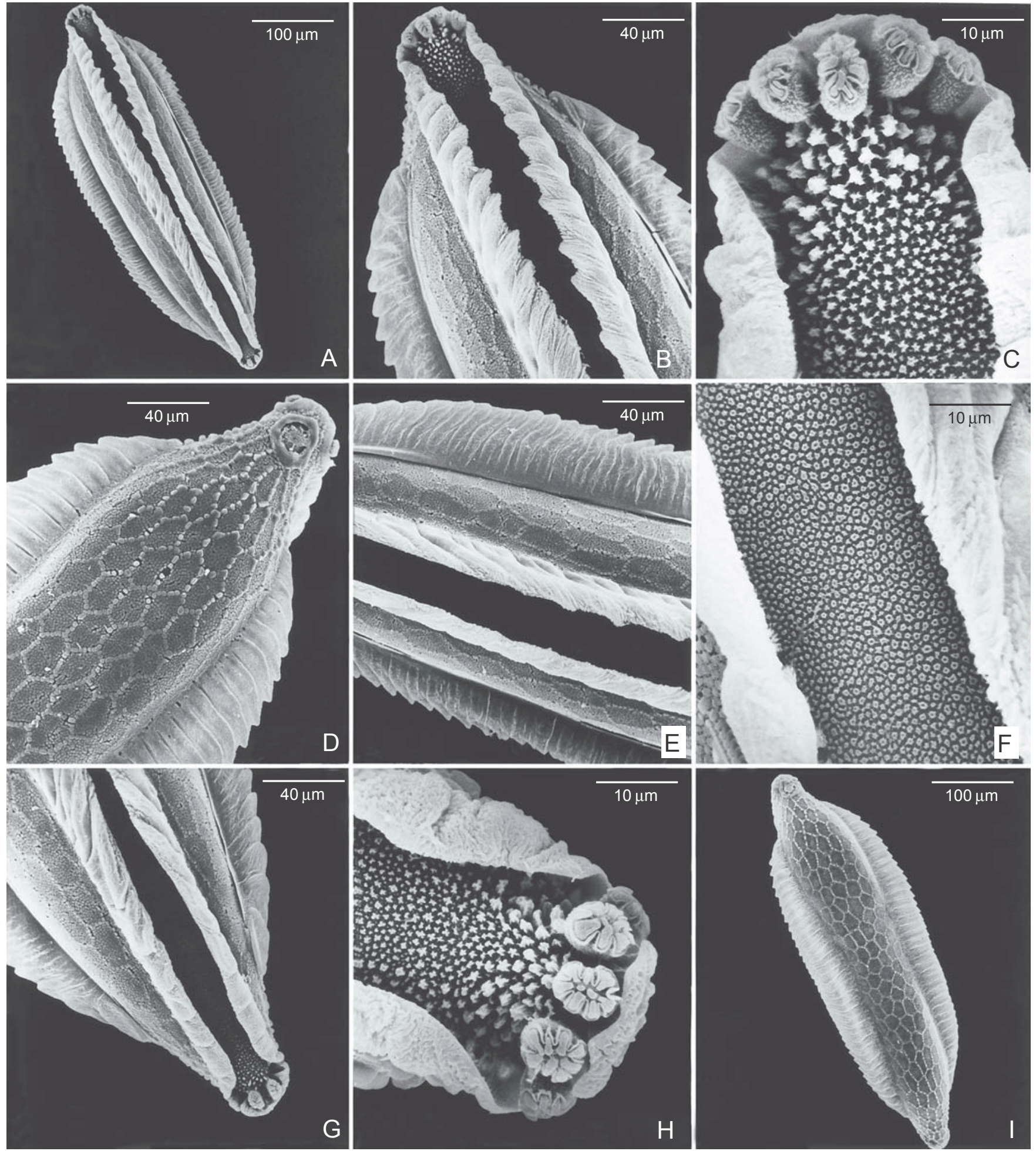

Fig. 3. Egg of Anopheles (Anopheles) mediopunctatus. A, entire egg, anterior end at top, dorsal view; B, anterior end, showing frill, dorsal view; $\mathbf{C}$, anterior end, showing detail of deck tubercles and lobed tubercles, dorsal view; D, anterior end, ventral view, showing microphyle and outer chorionic cells; $\mathbf{E}$, middle region of egg, showing frill and floats, dorsal view; $\mathbf{F}$, deck tubercles, middle region, dorsal view; $\mathbf{G}$, posterior end, showing detail of frill, dorsal view; $\mathbf{H}$, posterior end, showing detail of deck tubercles and lobed tubercles; I, entire egg, anterior end at top, ventral view. 

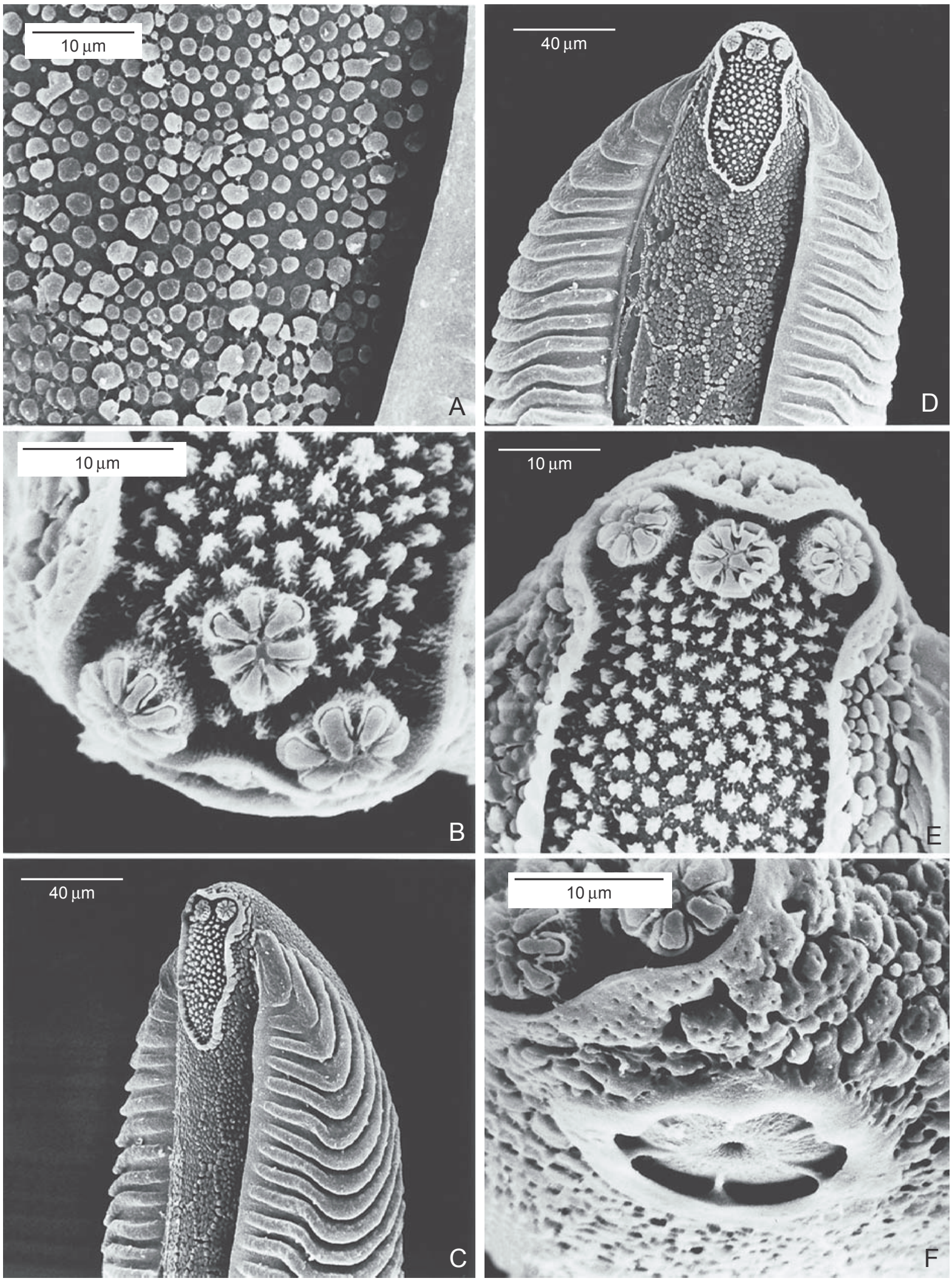

Fig. 4. Egg of Anopheles (Anopheles) forattinii. A, deck tubercles, dorsal view; B, anterior end, showing detail of lobed tubercles and deck tubercles, dorsal view; C, posterior end, showing floats, dorsolateral view; D, posterior end, showing floats and deck; E, posterior end, showing detail of lobed tubercles and deck tubercles; $\mathbf{F}$, anterior pole, showing micropyle, anteroventral view. 
smooth at top (Fig. 3D); tubercles connected by narrow bridges. Outer chorionic reticulum distinct, formed of slightly raised tubercles, larger than those found inside cells (Fig. 3D,I). Floats well displaced ventrally, shallow, long, extending along egg except at anterior and posterior ends, ribs about 34-37 in number, slightly divided into irregular lobes (Fig. 3A,E,I).

\section{DISCUSSION}

CAUSEY et al. (1944) pointed out that the eggs of specimens identified as A. mediopunctatus from several localities in Brazil had distinct morphological features depending on the locality where the adults were collected. Although the limited resolution of the light microscopic drawings of each distinct type of egg, it seems that the drawing of the "typical" egg of A. mediopunctatus shown in Plate I (CAUSEY et al. 1944) is not, in fact, of A. mediopunctatus, but from either A. costai or $A$. forattinii. The egg of $A$. costai (Figs. 1,2) seems to be indistinguishable from that of $A$. forattinii from Peru (Fig. 4). One of the drawings of eggs considered "atypical" by CAUSEY et al. (1944) (Plate II, j) seems to be of A. mediopunctatus because it has a continuous ridge extending along dorsal surface of egg, enclosing the deck. The other two "atypical" eggs (Plate II, h, i) may be of either A. costai or A. forattinii.

In comparison with the eggs of related species of the Arribalzagia Series examined under scanning electron microscope, the egg of $A$. mediopunctatus is more similar to those of A. fluminensis Root, 1927 and A. intermedius (Peryassu, 1908) in having shallow floats, well displaced ventrally, and frill modified into prominent dorsal ridges, which extend along egg length encircling deck region. LouniBos et al. (1997) pointed out that the egg of A. mediopunctatus is distinct from that of $A$. fluminensis in having the central deck more exposed, and a dorsal ridge coalesced into whorls, whereas in A. fluminensis the frill overlaps dorsally, almost hiding the deck region, and the dorsal ridge does not coalesce into whorls. Additionally, in A. mediopunctatus the dorsal ridges are continuous along egg surface enclosing both anterior and posterior poles, whereas in A. fluminensis the dorsal ridges extend along the egg except for the anterior and posterior poles. The egg of $A$. intermedius is easily distinguished from that of $A$. mediopunctatus because the deck region is well exposed, not hidden by overlapping frills, the dorsal ridges are oblique to the long axis of the egg, and similar to the egg of $A$. fluminensis do not encircle both anterior and posterior poles of the egg.

Although morphologically similar to $A$. costai and $A$. forattinii in the adult stage, male genitalia structures and fourth-instar larva and pupa, the egg of A. mediopunctatus is distinct from those of $A$. costai and A. forattinii. The eggs of these two species do not have the frill developed in a dorsal ridge enclosing the deck region, and the floats are swollen and positioned laterally. In fact, the eggs of $A$. costai and $A$. forattinii most resembles those of $A$. punctimacula Dyar \& Knab, 1906 (RodRIGUEz et al. 2002) in having the frill forming a narrow, dorsal collar at both the anterior and posterior ends of the egg, the areas encircled by the collar somewhat oval in outline, and with the deck region and ventral surface covered with hexagonal chorionic cells. However, the eggs of $A$. costai and $A$. forattinii can be distinguished from that of $A$. punctimacula in having the floats long, extending almost the entire length of the egg except for anterior and posterior ends, whereas they are short in A. punctimacula. Additionally, in $A$. costai and $A$. forattinii the frill encircles both the anterior and posterior poles of the egg (Fig. 1D,E; 4C,D,E), while in $A$. punctimacula frill is interrupted at the level of the lobed tubercles (see Fig. 4A,B in Rodriguez et al. 2002).

Acknowledgment. To Mr. Roberto Fernandez for providing eggs of Anopheles (Anopheles) forattinii.

\section{REFERENCES}

Causey, O. R.; L. M. Deane \& M. P. Deane. 1944. An illustrated key to the egg of thirty species of Brazilian Anophelines, with several new descriptions. The American Journal of Hygiene 39(1): 17.

FonseCA, F. DA; A. S. Ramos. 1940. Novo subgênero e novas espécies de anofelinas Neotropicas (Diptera: Culicidae). Memórias do Instituto Butantan 13: 383-387.

Forattini, O. P.; M. A. M. Sallum \& D. C. Flores. 1997. Description of the egg of Anopheles (Anopheles) intermedius (Peryassu, 1908) (Diptera: Culicidae) by scanning electron microscopy. Revista do Instituto de Medicina Tropical de São Paulo 39(1): 5-9.

Lane, J. 1953. Neotropical Culicidae. São Paulo, Editora da Universidade de São Paulo, 548 p.

Lounibos. L. P., D. Duzak; J. R. Liley \& R. LouRenço-DE-oliveira. 1997. Egg structure of Anopheles fluminensis and Anopheles shannoni. Memórias do Instituto Oswaldo Cruz 92(2): 221-232.

Pecor, J. E.; V. L. Mallampalli; R. E. Harbach \& E. L. Peyton. 1992. Catalog and illustrated review of the subgenus Melanoconion of Culex (Diptera: Culicidae). Contributions of the American Entomological Institute (Ann Arbor) 27(2): 1-228.

Rodriguez, M. H.; B. Chavez; A. Ulloa \& J. I. Arredondo-Jimenez. 2002. Fine structure of the eggs of Anopheles (Anopheles) punctimacula. Journal of the American Mosquito Control Association 18(1): $1-9$.

Sallum, M. A.; R. C. Wilkerson \& O. P. Forattini. 1999. Taxonomic study of species formerly identified as Anopheles mediopunctatus and resurrection of An. costai (Diptera: Culicidae). Journal of Medical Entomology 36(3): 282-300.

Sallum, M. A. M.; T. R. Schultz \& R. C. Wilkerson. 2000. Phylogeny of Anophelinae (Diptera: Culicidae) based on morphological characters. Annals of the Entomological Society of America 93(4): 745-775.

Sallum, M. A. M.; T. R. Schultz; P. G. Foster; K. Aronstein; R. A. Wirtz \& R. C. Wilkerson. 2002. Phylogeny of Anophelinae (Diptera: Culicidae) based on nuclear ribosomal and mitochondrial DNA sequences. Systematic Entomology 27(3): 361-382.

Theobald, F. V. 1903. A monograph of the Culicidae or mosquitoes, vol. 3. London. British Museum (Natural History), xvii+548 p.

Wilkerson, R. C. 1988. Notes and rdescriptions of some Anopheles Series Arribalzagia holotypes (Diptera: Culicidae) in the British Museum (Natural History). Proceedings of the Entomological Society of Washington 90: 411-421.

Wilkerson, R. C. \& E. L. Peyton. 1990. Standardized nomenclature for 
the costal wing spots of the genus Anopheles and other spottedwing mosquitoes (Diptera: Culicidae). Journal of Medical Entomology 27(2): 207-224.

Wilkerson, R. C. \& M. A. M. Sallum. 1999. Anopheles (Anopheles) forattinii: a new species in Series Arribalzagia (Diptera: Culicidae). Journal of Medical Entomology 36(3): 345-54.

Received 01.VIII.2003; accepted 25.II.2004 